Original Article

\title{
FORMULATION AND IMMUNOSTIMULANT STABILITY POLYSACCHARIDE SYRUP OF FRACTION NONI (MORINDA CITRIFOLIA L.) FRUITS
}

\section{EDIATI S. ${ }^{*}$, T. N. SAIFULLAH S. ${ }^{2}$, RUMIYATI R. ${ }^{1}$, DUNSTANIA M. M. ${ }^{3}$, MARIA QUEEN P. ${ }^{3}$, ERNA MARIANA S. ${ }^{3}$}

${ }^{1}$ Departement of Pharmaceutical Chemistry, Faculty of Pharmacy, Universitas Gadjah Mada, Yogyakarta, Indonesia, ${ }^{2}$ Departement of Pharmaceutics, Faculty of Pharmacy, Universitas Gadjah Mada, Yogyakarta, Indonesia, ${ }^{3}$ Undergraduate program, Faculty of Pharmacy, Universitas Gadjah Mada, Yogyakarta, Indonesia

Email: ediati_far@ugm.ac.id

Received: 13 May 2019, Revised and Accepted: 06 Aug 2019

\begin{abstract}
Objective: The study aimed to formulate standardized polysaccharide fraction of Noni (SPFN) fruit into syrup preparations to fulfill the acceptability requirement of National Agency of Drugs and Food Control [Badan Pengawas Obat dan Makanan Republik of Indonesia (BPOM RI)] so
\end{abstract} that it can be used in the community as an immunostimulant.

Methods: The optimization of the formula A and B were done using Simplex Lattice Design (SLD) method and its stability tested under extreme temperature change effect using thaw cycling method by evaluating the physical properties, microbial contamination and immunostimulant activity. MTT method was used to determine the immunostimulant activity of syrup against lymphocyte proliferation in vitro.

Results: Based on the results of stability tests of formula A using $\mathrm{pH}$ (4.45), viscosity (81.03 mPas), taste (good taste), pouring power (2.31 s), amount of bacteria ( 68 colonies $/ \mathrm{ml})$, total yeast and mold $(269$ colonies $/ \mathrm{ml})$ parameters and fulfilled the acceptability requirement of BPOM RI. Formula A could maintain better stability than formula B. Formula A syrup used for immunostimulant activity testing that could increase lymphocyte proliferation at a concentration of 13.33 to $106.64 \mu \mathrm{g} / \mu \mathrm{l}$ and it's stable under the influence of extreme temperature changes.

Conclusion: Formula A could be used to produce SPFN syrup, which has stable physical properties and immunostimulant activity beside no microbial contamination that fulfill requirements of BPOM RI.

Keywords: Noni fruit, Polysaccharide, Syrup, Thaw cycling, MTT, Immunostimulant

(C) 2019 The Authors. Published by Innovare Academic Sciences Pvt Ltd. This is an open-access article under the CC BY license (http://creativecommons.org/licenses/by/4.0/) DOI: http://dx.doi.org/10.22159/ijap.2019v11i5.34090

\section{INTRODUCTION}

Polysaccharides are the polymers of monosaccharides and most are polymer of glucose [1]. Most of the polysaccharides found in plants are high molecular weight polysaccharides which generally have immunomodulatory activities [2]. According to several studies, polysaccharides can cause various immunomodulatory effects on animal tissues, blood, digestive tract and spleen. Polysaccharides that taken orally was able to stimulate the immune system in the blood of healthy adults [3]. Immunostimulant activity of Morinda citrifolia is related to its antitumor activity [4]. Noni fruit polysaccharides have antitumor activity against Lewis Lung Carcinoma (LLC) in mice by suppressing tumor growth through immune system activation [5]. Extract of Morinda citrifolia was able to stimulate cannabinoid receptors (CB2) with decreased IL-4 and increase IFN-gamma [6]. Noni fruit polysaccharide fraction was reported to be able to increase lymphocyte proliferation and macrophage phagocytosis in vitro [7]. It has been done the standardize of a polysaccharide fraction of Noni fruit (SPFN) collected from the district of Yogyakarta, Indonesia with glucose as a marker [8]. The use of Noni fruit as an immunostimulant is designed to be a pharmaceutical product, so it can be used in the community. The solution has to easily distributed and drugs dissolved in a liquid carrier. Solid, liquid, gas molecules can be distributed between carrier molecules. Syrup that has been dissolved in liquids can increase application in the stomach, skin and other administrative pathways faster than other dosage forms [9]. Therefore efficacious substances are formulated in the form of syrup due to the absorption in form of liquids [10]. Syrup preparations contain excipients such as preservatives, sweeteners, thickeners and other ingredients used to facilitate the route of the preparation, protect or improve physical and chemical stability and increase the solubility of the active ingredients in preparation [11]. The quality requirements for syrup are microbial number (mold/yeast number and total plate number) [12] and physical properties. Physical tests for syrup preparations include organoleptic, viscosity, ease of pouring and $\mathrm{pH}$.
Organoleptic test of syrup preparation was carried out using questionnaires by 20 respondents. The greater the value (1-4 scale) obtained, the better the taste of syrup. Syrup evaluation results indicate that syrup has good taste[13, 14]. Syrup preparation must have good viscosity and flow properties. The viscosity value has a relationship with the pouring value of a liquid. If the viscosity decreases, the pouring time is faster, because the fluidity of solution is inversely proportional to viscosity [15]. Viscosity values and pouring capacity of syrup preparations do not have certain of requirements, this evaluation considers the ease of preparation to flow from its place, and stability of the preparation. The viscosity value of the preparation is $81.03 \mathrm{mPas}$ and the pouring power is 2.31 seconds. Syrup preparations are designed to have a $\mathrm{pH}$ value of around 4-6 [16, 17]. This value considers the taste of the preparation so that it can be taken orally. Syrup preparation has a pH of around 4.45, contain excipients such as preservatives, sweeteners, thickeners and other ingredients used to facilitate the route of preparation, protect or improve physical and chemicals stability and increase the solubility of the active ingredients [11] Therefore, it is necessary to evaluate formulation of syrup with modification of thickening agents. The use of one the thickening agents selected, CMC sodium and xanthan gum to obtain more stable formula [18].

The stability of syrup during storage was expected to influence immunostimulant activity. Some previous researches related to these topic have been done for example; influence of Morinda citrifolia $\mathrm{L}$. fruit extract as adjuvant on IgY production raised in laying chickens against avian influenza [19], optimization of polysaccharide-rich fractionation from Morinda citrifolia L., fruit-based on immunostimulatory effect in vitro [7], polysaccharide-rich fraction of noni fruit (Morinda citrifolia L.) as doxorubicin co-chemotherapy: evaluation on catalase, macrophage and TCD8+lymphocyte [20], characterization of purified polysaccharide fraction of Morinda citrifolia L. Fruit [8] and development of standardized product of polysaccharide fraction of noni fruit (Morinda Citrifolia L.). However, there is no detail information regarding the optimum formula of the syrup to be developed as immunostimulant containing fraction of the 
noni fruit. Furthermore, results of these research will provide benefit information for development of the formula.

\section{MATERIALS AND METHODS}

\section{Materials}

Sample of noni fruits that used was collected from the district of Yogyakarta, Indonesia as standardized polysaccharide fraction of noni fruit [(SPFN) produced by PT. Phytochemindo Reksa, Bogor, Indonesia]. Benzoate sodium, carboxy-methyl-cellulose sodium, citric acid, citrate sodium, propylene glycol, sucrose and MTT were obtained from Merck. The lymphocyte cells proliferation test involved male Balb/C mice, aged of 2-3 mo, weighed of 25-30 g.

\section{Methods}

Design of the research was experimental research. The manufacture of SPFN syrup using two different formulas, then each syrup was evaluated. The stability test used Freeze-Thaw Cycling (FTC) method for 3 cycles. The syrup parameters were observed by organoleptic, $\mathrm{pH}$, viscosity, ease of pouring, yeast mold number and total plate number. The most stable syrup was tested its lymphocyte cell proliferation using MTT method.

\section{Preparation of SPFN}

The dried powder of Noni fruit was macerated with $75{ }^{\circ} \mathrm{C}(1: 20 \mathrm{w} / \mathrm{v})$ for 30 min the macerate obtained was evaporated and $95 \%$ ethanol was added for $30 \mathrm{~min}$, then filtered [21]. The fraction obtained was dark brown, had a distinctive aroma and taste. Evaluation of microbial content showed the fraction fit in the required quality.

\section{Stability testing}

Stability test was carried out by FTC method for 3 cycles. The preparations were stored in a row at freezing temperature $\left( \pm 0{ }^{\circ} \mathrm{C}\right)$ for $24 \mathrm{~h}$, room temperature $\left( \pm 30^{\circ} \mathrm{C}\right)$ for $24 \mathrm{~h}$. After melting the preparations were stored again at hot temperature $\left( \pm 45^{\circ} \mathrm{C}\right)$ for $24 \mathrm{~h}$ and room temperature $\left( \pm 30^{\circ} \mathrm{C}\right)$ for $24 \mathrm{~h}$ [22]. Syrups will stable during the transportation process if it is able to maintain the parameters under FTC for 3 cycles.

\section{Lymphocyte isolation and proliferation assay}

The lymphocyte was isolated from Balb/c mice's spleen. The Balb/c mice (male, aged 2-10 w old, 25-30 g) were purchased from Gadjah Mada University Integrated Research and Testing Laboratory.[Approval Letter no. 00130/04/IPPT/X/2017]. Animals were acclimatized for a period of $24 \mathrm{~h}$ to ensure their suitability for research. Lymphocyte cells were isolated and suspended into complete RMPI medium. The lymphocyte cells suspension of $100 \mu \mathrm{l}$ $\left(2 \times 10^{6}\right.$ cells $\left./ \mathrm{ml}\right)$ medium was distributed into 96 wells microplate according to the treatment groups. Hepatitis B vaccine was added 10 $\mu \mathrm{l}$ per well and then incubated in an incubator with $5 \% \mathrm{CO} 2$ at $37^{\circ} \mathrm{C}$ for $24 \mathrm{~h}$. The next step was added $100 \mu \mathrm{l}$ sample of syrup and solution of SPFN (as a comparison) in various concentrations and then incubated again for $48 \mathrm{~h}$. Solution of $5 \mathrm{mg} / \mathrm{ml}$ MTT was added 10 $\mu \mathrm{l} /$ well and reincubated for $4 \mathrm{~h}$, then $50 \mu \mathrm{l}$ stop solution (10\% SDS in $0.01 \mathrm{~N} \mathrm{HCl}$ ) added, followed by incubation at room temperature in a dark place overnight. The Optical Density (OD) value was measured using a microplate reader at a wavelength of $550 \mathrm{~nm}$ [12].

\section{Determination of the dosage of a fraction}

Previous studies showed that SPFN dosage of $25-50 \mathrm{mg} / \mathrm{kg}$ body weight could increase the number of macrophages that play role in the immune system [7]. This study used a dosage of $50 \mathrm{mg} / \mathrm{kg}$ body weight for adult human. So to prepare $60 \mathrm{ml}$ of syrup was needed of $800 \mathrm{mg} \mathrm{SPFN}$.

\section{Preparation of syrup}

Syrup polysaccharide fraction of noni fruit (SPFN) was prepared by two formulas with the different on thickening agent. Formula $A$ used xanthan gum and formula B used CMC sodium as thickening agent (table 1).

The formulas have been optimized by simplex lattice design method. The syrup was prepared by dissolving SPFN and sucrose in warm water. The solution SPFN and sucrose was added with propylene glycol, buffer, and preservative and then stirred using a mixer. Propylene glycol was used as a cosolvent and stabilizing agent [23] for helping the solubility of citric acid, sodium citrate and benzoate sodium. Formula A was added with xanthan gum as thickener, while formula B was added with CMC sodium, then a solution of SPFN and essence was added to each formula.

Table 1: Syrup formulas of a polysaccharide fraction of noni fruit (SPFN) with various thickening agents

\begin{tabular}{lll}
\hline Ingredients & Formula A & FFo Formula B \\
\hline 1. SPFN (1:1) (mg) & 800 & 800 \\
2. Propylene glycol (\%) & 5 & 5 \\
3. Citric acid (\%) & 0.2 & 0.2 \\
4. Sodium citrate (\%) & 0.3 & 0.3 \\
5. Xanthan gum (\%) & 0.15 & - \\
6. CMC sodium (\%) & - & 0.2 \\
7. Benzoate sodium (\%) & 0.1 & 0.1 \\
8. Sucrose (\%) & 59.5 & 47.5 \\
9. Essence & q. s. & q. s. \\
10. Distilled Water up to (ml) & 60 & 60 \\
\hline
\end{tabular}

Notes: SPFN (1:1): Mix of SPFN: Lactose $=1: 1$

\section{Stability test of the formula syrups}

The two of formula syrups stability were evaluated against organoleptic tests by using questionnaires [13]. The stability of both formula syrup also was observed against viscosity, ease of pouring, $\mathrm{pH}$, microbial, yeast molds and total plate number after receiving the freeze-thaw test. The freeze-thaw test was carried out for 3 cycles, where the first cycle takes place of $24 \mathrm{~h}$ at cold temperatures, $24 \mathrm{~h}$ at room temperature, $24 \mathrm{~h}$ at hot temperatures and back to $24 \mathrm{~h}$ at room temperature. Every end of the cycle, the formula syrups were evaluated to determine its stability [21].

\section{Selected formula}

Based on the evaluation of stability test, one optimum syrup was selected. The selection based on the results of organoleptic test, viscosity test, ease of pouring test, $\mathrm{pH}$ test, microbial number test and evaluation of stability test for both formulas.

\section{Lymphocyte cell proliferation test from the selected formula}

The selected formula, then it was tested against lymphocyte cell proliferation by MTT Assay. Lymphocyte cells were isolated from spleen of Balb/C mice. The lymphocyte cells suspension in the $100 \mu \mathrm{l}\left(2 \times 10^{6} \mathrm{cells} / \mathrm{ml}\right)$ medium was distributed into 96microplate well according to the treatment group. For inducing immune response was done by adding $10 \mu \mathrm{l}$ hepatitis B vaccine to each well and then incubated for $24 \mathrm{~h}$ in an incubator with $5 \%$ $\mathrm{CO}_{2}$ at $37^{\circ} \mathrm{C}$. The next step was added $100 \mu \mathrm{l}$ of syrup in various concentration and $100 \mu$ l solution of SPFN (as a comparison) and then incubated again for $48 \mathrm{~h}$ in incubator. Then added $10 \mu \mathrm{l}$ of MTT $5 \mathrm{mg} / \mathrm{ml}$ and incubated for $4 \mathrm{~h}$ in incubator. After incubation, $50 \mu \mathrm{l}$ of stop solution $(10 \%$ SDS in $0.01 \mathrm{~N} \mathrm{HCl})$ was added and then incubated at room temperature for $15 \mathrm{~min}$ until color changes occur. The OD measurements using microplate readers by a wavelength of $650 \mathrm{~nm}$. 


\section{RESULTS}

Results of formula syrup stability test after receiving extreme temperature treatment of FTC method 3 cycles. The data obtained after the formula A and formula B syrups receiving extreme temperature treatment of FTC method for 3 cycles, were showed in table 2, fig. 1, 2 and 3. Formula B syrup changed significantly since cycle 1 , these were characterized by the microbial number (table 2), the profile of viscosity (fig. 1), the profile of pH (fig. 2), and the profile of pouring power (fig. 3 ) as the parameters of formula $A$ and formula B syrup after receiving FTC method for 3 cycles. Each point of fig. 1, 2 and 3 represented as mean $\pm S D(n=4)$.

Table 2: Microbial number of formula A and B syrup

\begin{tabular}{lllll}
\hline \multirow{2}{*}{ Cycle } & Amount of yeast and mold (colonies/ml) & Total plate number (colonies/ml) \\
\cline { 2 - 5 } & Formula A & Formula B & Formula A \\
\hline 0 & 440 & 140 & 50 & Formula B \\
1 & 40 & 100 & 80 & 100 \\
2 & 400 & 60 & 120 & 230 \\
3 & 60 & 60 & 100 & 100 \\
\hline
\end{tabular}

mean \pm SD (Standard deviation), $\mathrm{n}=4$

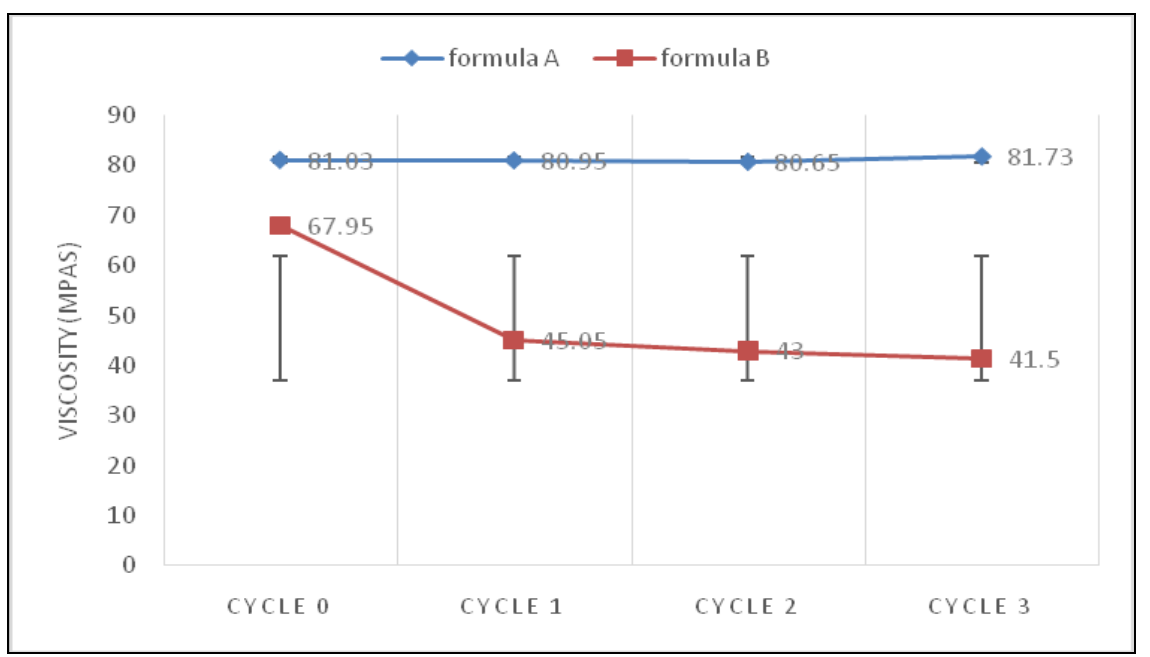

Fig. 1: The viscosity profile of formula $A$ and formula $B$ syrup mean $\pm S D$ (Standard deviation), $n=4$

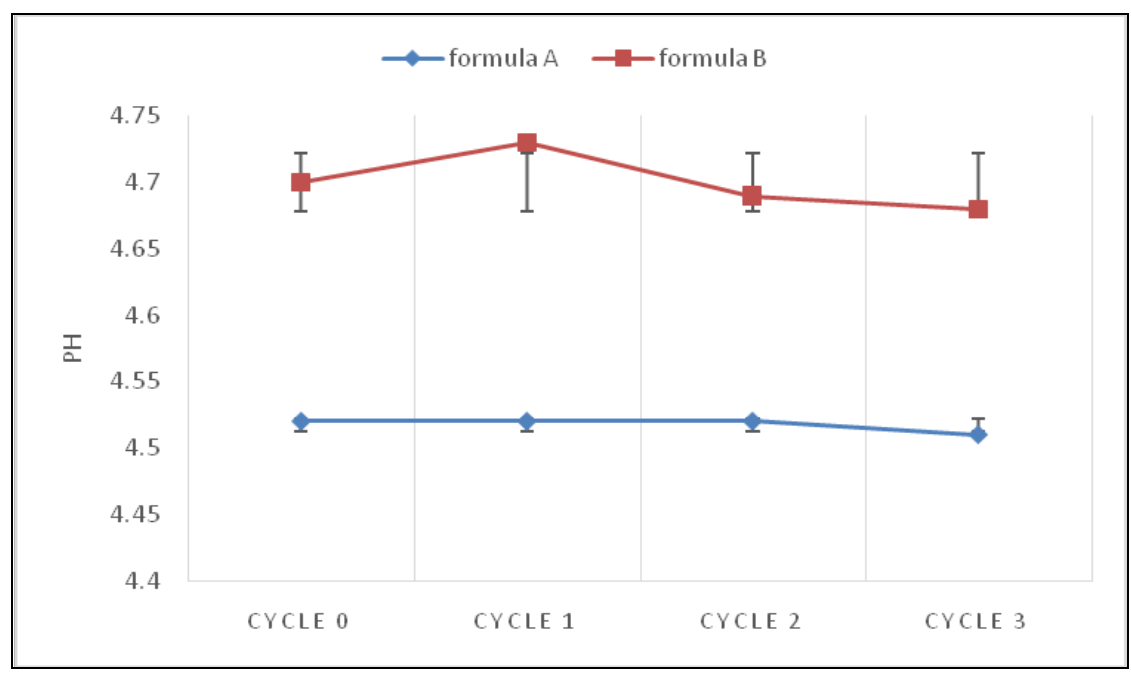

Fig. 2: The $\mathrm{pH}$ profile of formula $A$ and formula B syrup mean $\pm S D$ (Standard deviation), $n=4$

\section{Results of lymphocyte cells proliferation}

The result of lymphocyte cells proliferation obtained from cells was cultured with test samples [SPFN solution and the selected formula (formula A) of SPFN syrup, briefly as SPFN syrup] for $48 \mathrm{~h}$. Cell viability determined using MTT assay. The SPFN solution and SPFN syrup could significantly increase lymphocyte cells proliferation (fig. 4). The SPFN solution (fig. A) showed a significant increase at concentration 53.32 $\mu \mathrm{g} / \mu \mathrm{l}$. The highest level of lymphocyte cell proliferation showed at a concentration of $106.64 \mu \mathrm{g} / \mu \mathrm{l}$. The results showed an increase of lymphocyte cells proliferation affected by the concentration of the SPFN solution. Based on the results of statistical analysis, there was no significant $(\mathrm{p}<0.05)$ difference between the OD of SPFN solution and SPFN syrup (fig. 4 B) in the majority of the polysaccharide fraction 
concentration. Therefore, the SPFN syrup did not affect the immunostimulant activity The SPFN solution and SPFN syrup, for stability test, both also received extreme temperature treatment of FTC method for 3 cycles. The OD values obtained after receiving FTC method showed significant differences of SPFN solution at concentration 13.33 $\mu \mathrm{g} / \mu \mathrm{l} ; 53.32 \mu \mathrm{g} / \mu \mathrm{l}$ and $79.98 \mu \mathrm{g} / \mu \mathrm{l}$ respectively (fig. $5 \mathrm{~A}$ ), while the OD values obtained after receiving FTC method of SPFN syrup (fig. 5B) did not show a significant differences in all concentrations.

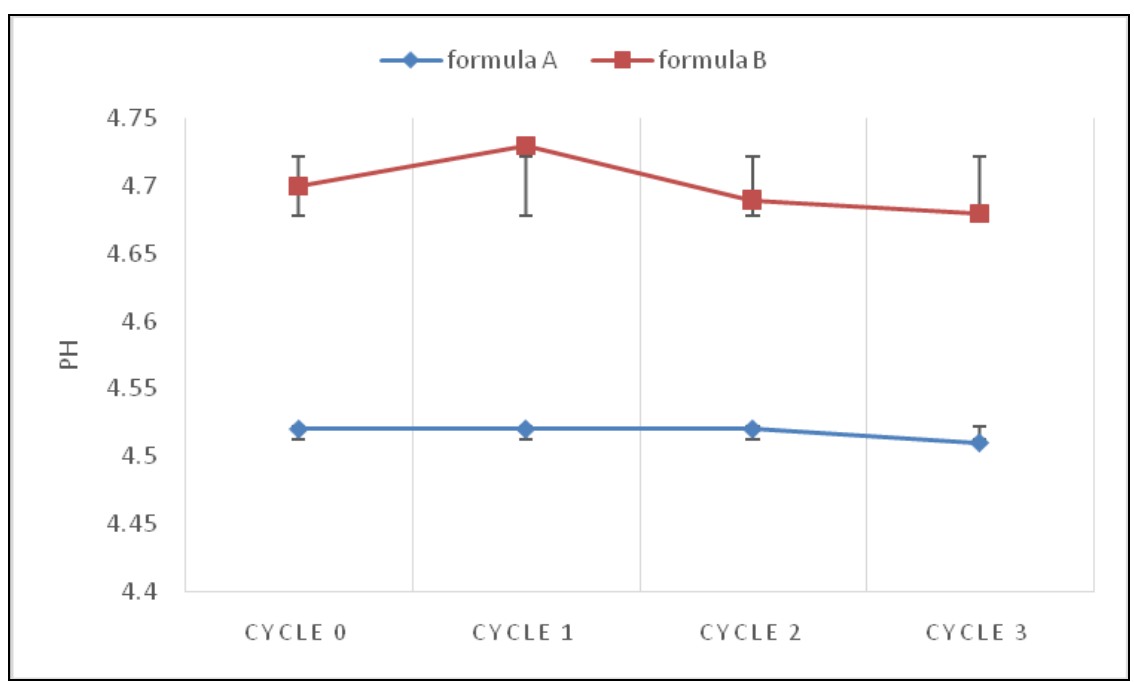

Fig. 3: The ease of pouring profile of formula $A$ and formula B syrup mean \pm SD (Standard deviation), $n=4$
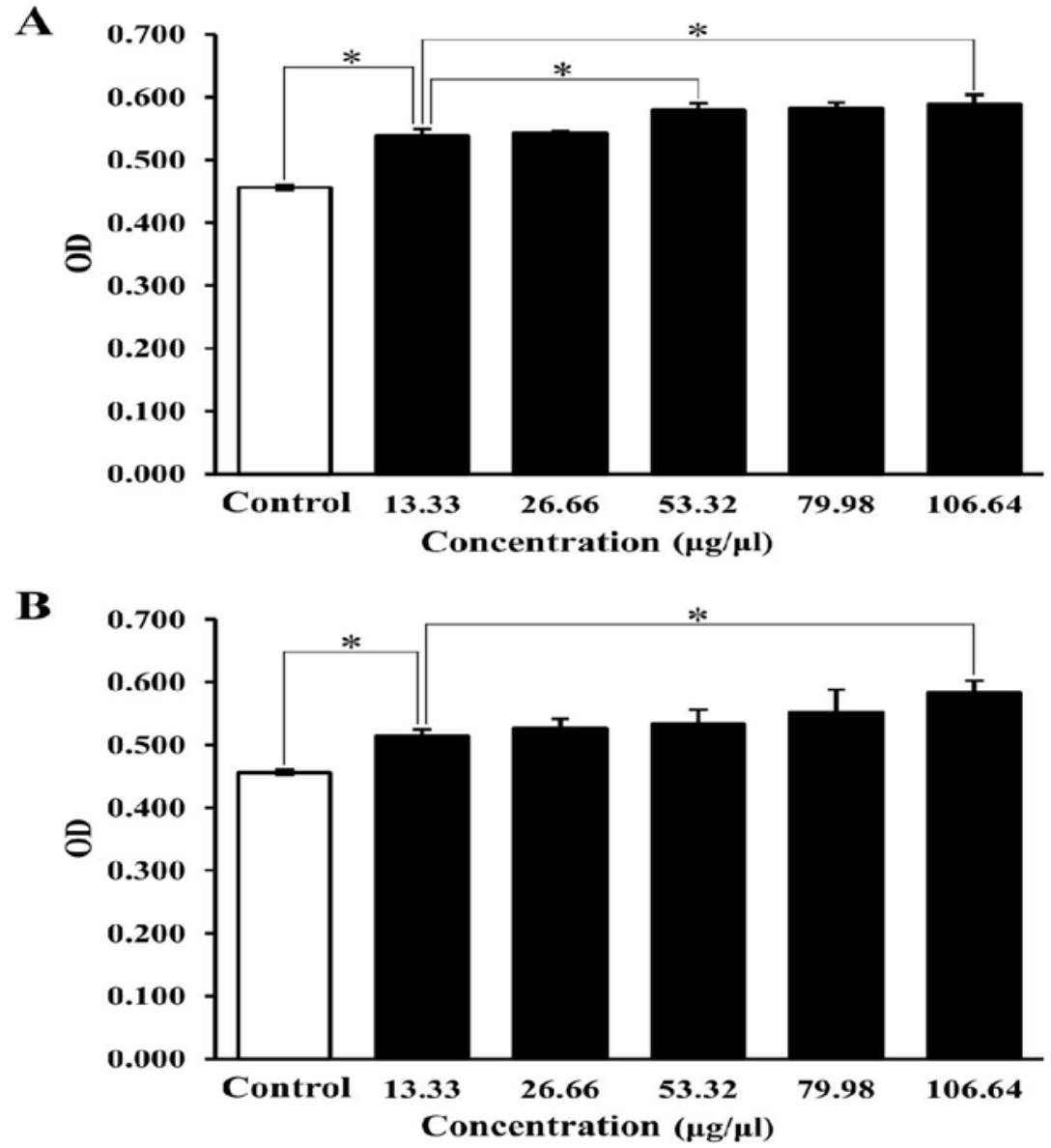

Fig. 4: Lymphocyte Proliferation profile of SPFN solution (A) SPFN syrup (B), each stem represented as mean \pm SD (n = 3). ${ }^{*}$ < $<0.05$ 


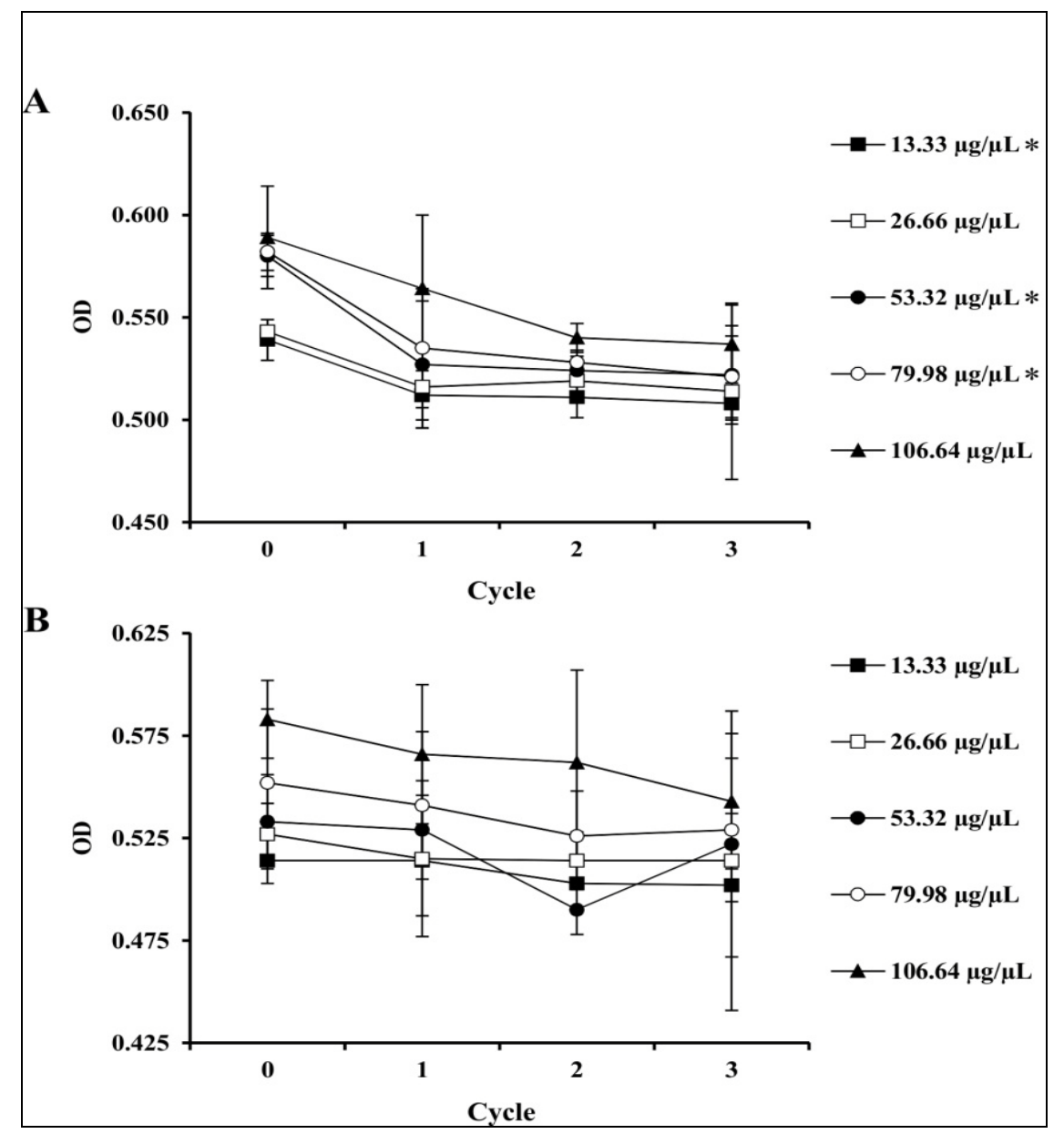

Fig. 5: The profile of stable immunostimulant activity of SPFN solution, (A) SPFN syrup, (B) Each point represented as mean \pm SD ( $n=3$ ), ${ }^{*}<<0.05$

\section{DISCUSSION}

The organoleptic tests were to evaluate the acceptability of syrup preparations by patients. The optimum syrup of formula $\mathrm{A}$ and formula B showed that both have a sweet taste, dark brown flavor and a distinctive aroma. The viscosity test showed that the average viscosity optimum of formula A syrup was $81.03 \mathrm{mPas}$ and average viscosity optimum of formula B syrup was $67.95 \mathrm{mPas}$. The greater amount of sucrose and thickeners, the greater viscosity of syrup, but the viscosity in this study is dominated by sucrose. Xanthan gum and CMC sodium have different thickening levels, so in the same amount, the resulting thickness was different. The ease of pouring test illustrated it off from the bottle. Formula A has an average pouring time 2.31 seconds while formula B has 2.13 seconds. The less viscosity, the faster pouring time, because the fluidity of a solution is inversely proportional to viscosity [14]. The $\mathrm{pH}$ test showed that both formula $A$ and formula B syrup have an average acidity level of 4.51. This was because the buffer has maintained the acidity level of the syrup. The microbial number test result from each formula was still entering the range required by BPOM RI. Formula A has amount of yeast molds 440 colonies/ml while formula B has 140 colonies $/ \mathrm{ml}$, from the requirements less than 1.000 colonies $/ \mathrm{ml}$. and total plate number, Formula $\mathrm{A}$ has amount of total plate 50 colonies $/ \mathrm{ml}$ while formula $\mathrm{B}$ has 100 colonies $/ \mathrm{ml}$, from the requirements less than 10.000 colonies/ml have the microbial number that was still fulfill the BPOM RI requirements [12] shown in table 2 . Formula B syrup changed significantly since cycle 1 , this was characterized by a decrease in viscosity, pouring power and up and down $\mathrm{pH}$ values that appear in fig. 1,2 and 3. While formula $\mathrm{A}$ has the same viscosity from cycle 0 to cycle 3 ends. Therefore, formula A is more stable based on physical and microbiological parameters under extreme temperature treatment. The SPFN solution and SPFN syrup can significantly increase lymphocyte cell proliferation.
Standardized polysaccharide fraction of Noni fruit showed a significant increase at concentration $53.32 \mu \mathrm{g} / \mu \mathrm{l}$. The highest level of lymphocyte cell proliferation showed at a concentration of 106.64 $\mu \mathrm{g} / \mu \mathrm{l}$. This showed an increase of lymphocyte cells were affected by the concentration of the polysaccharide fraction. Based on the results of statistical analysis, there was no significant difference between the OD of SPFN solutions in the majority of the polysaccharide fraction concentration. Therefore, the formulation does not affect the immunostimulant activity of syrup. The OD values of FTC solution showed significant differences at concentration of $13.33 \mu \mathrm{g} / \mu \mathrm{l} ; 53.32 \mu \mathrm{g} / \mu \mathrm{l}$ and $79.98 \mu \mathrm{g} / \mu \mathrm{l}$ respectively, while the OD values of FTC syrup did not show a significant difference in all concentrations. Therefore, the SPFN syrup is more stable in its immunostimulant activity compared to SPFN solution. This phenomenon showed that formula A of polysaccharide fraction into syrup with formula A, stable physically, microbial number and immunostimulant activity. Therefore, the SPFN syrup was more stable in its immunostimulant activity compared to the SPFN solution. This phenomenon showed that formulation of polysaccharide fraction into syrup form was more stable in physically, microbiology and immunostimulatory activity.

\section{CONCLUSION}

Formula A could be used to produce SPFN syrup which has a stable physical properties and immunostimulant activity beside no microbial contamination that fulfill requirements of BPOM RI

\section{ACKNOWLEDGMENT}

All authors thank to Faculty of Pharmacy, Universitas Gadjah Mada, for the grant by contract number of UGM/FA/1678. a/M/05/01 through Kegiatan Penelitian Perguruan Tinggi Program Hibah Inkubasi Riset Tahun 2017 and any kinds of support. 


\section{AUTHORS CONTRIBUTIONS}

All the authors have contributed equally

\section{CONFLICT OF INTERESTS}

Declared none

\section{REFERENCES}

1. What are polysaccharides?-Edinformatics. Available from: https://www.edinformatics.com/math_science/what_are_poly saccharides.htm [Last accessed on 07 May 2019]

2. Cseke LJ, Kirakosyan A, Kaufman PB, Warber S, Duke JA, Brielman HL. Natural product from plant. $2^{\text {nd }}$ ed. CRC Press. USA; 2016. p. 27-30.

3. Ramberg JE, Nelson ED, Sinnott RA. Immunomodulatory dietary polysaccharides: a systematic review of the literature. Nutr J 2010;9:54.

4. Wang M, West B, Jensen C, Nowicki D, Su C, Palu A, et al. Morinda citrifolia (noni). a literature review and recent advances in noni research. Acta Pharmacol Sin 2002;23:1127-41.

5. Hirazumi A, Furusawa E, Chou SC, Hokama Y. Immunomodulation contributes to the anti-cancer activity of morinda citrifolia (noni) fruit juice. Proc West Pharmacol Soc 1996;39:25-7.

6. Palu A, Hirazumi A, West B, Deng S, Jensen J, White L. The effects of Morinda citrifolia L. (noni) on the immune system: Its molecular mechanism of action. J Ethnopharmacol 2008;115:502-6.

7. Ediati S, Hertiani T, Kartika S, Maharani FP, Setiawan V, Narastika L. optimization of polysaccharide-rich fractionation from morinda citrifolia L., fruit based on immunostimulatory effect in vitro. Indonesian J Pharm 2015;26:78-85.

8. Ediati S, Lukitaningsih E, Rumiyati. Noni fruit as bioimmunostimulant material: characterization of a purified polysaccharide fraction of Morinda citrifolia L. fruit. The proceeding of DAAD conference on health management in post disaster recovery; 2017.

9. Kaushik A, Chauhan V, Sudha Dr. Formulation and evaluation of herbal cough syrup. Eur J Pharm Med Res 2016;3:517-22.

10. Supriyatna MW, Iskandar Y, Febriyanti MR. Prinsip obat herbal: sebuah pengantar untuk fitoterapi. Edisi 1. 47. Deepublish. Yogyakarta, Indonesia; 2014.
11. Jones DS. Pharmaceutics dosage form and design. $2^{\text {nd }}$ ed. Pharmaceutical Press: London; 2016. p. 1-21.

12. BPOM RI. Peraturan kepala BPOM No. 12 tahun 2014 tentang persyaratan mutu obat tradisional: BPOM. Jakarta; 2014. p. 15-6.

13. Hill R. What sample size is "enough" in internet survey research. Interpersonal Computing Technol: Electronic J 1998;6:1-12.

14. Mohammed K, Fatima B, Abdennour B, Lackhdar A. The fit between strategic choice and organization structure and their impact on the effectiveness of the organization: study of a set of medium and large instutution in Algeria. Int J Bus Soc Sci 2017;1:1-9.

15. Lisprayatna L, Bayu YM, Saifullah TNS. Formulasi sirup ekstrak daun legundi (Vitex trifolia L.). Trad Med J 2012;17:34-8.

16. Ansel HC, Allen LV, Popovich NG. Ansel's pharmaceutical dosage forms and drug delivery systems. Lippinacott Willliams and Wilkins. $9^{\text {th }}$ ed. United States of America; 2002. p. 374-9.

17. Allen LV, Ansel HC. Ansel's pharmaceutical dosage forms and drug delivery systems. $10^{\text {th }}$ ed. Lippincott Williams and Wilkins, Baltimore; 2014. p. 411-5.

18. Martin AN, Sinko PJ, Singh Y. Martin's physical pharmacy and pharmaceutical science. $6^{\text {th }}$ ed. Lippincott Williams and Wilkins, Philadelphia; 2011.

19. Ediati S, Harimurti S, Nurhidayat H, Anggoro W, Hikmawati EN, Wibowo JT, et al., Influence of Morinda citrifolia, L. fruit extract as adjuvant on Ig-Y production raised in laying chickens against avian influenza vaccine. Indonesian J Pharm 2012;2:115-20.

20. Ediati S, Hertiani T, Renggani TN, Asawimanda NA, Laksana BJ, Pratomo WP. The polysaccharide-rich fraction of noni fruit (Morinda citrifolia L.) as doxorubicin co-chemotherapy: evaluation of catalase, macrophages, and TCD8+lymphocytes. Sci Pharm 2015;83:479-88.

21. Chen XT, Li Y, Wang HL, Cheng WM, Zhang L, Ge JF. Immunomodulating effects of fractioned polysaccharides isolated from yuping-feng-powder in cyclophosphamidetreated mice. Am J Chin Med 2016;34:631-41.

22. Sambasivarao A, Baru CSR, Reddy MH. Accelerated stability testing of dosage forms as per International Conference of Harmonization (ICH) Guidelines. World J Pharm Med Res 2016;2:99-103.

23. Rowe RC, Sheskey PJ, Quinn ME. Handbook of pharmaceutical excipients. $6^{\text {th }}$ ed. Pharmaceutical Press: London; 2009. 